\title{
Transforming Sugarcane Bagasse and Vinasse Wastes into Hydrochar in the Presence of Phosphoric Acid: An Evaluation of Nutrient Contents and Structural Properties
}

\author{
Camila Almeida Melo ${ }^{1}$ - Francisco Holanda Soares Junior ${ }^{2}$ Marcia Cristina Bisinoti ${ }^{1}$. \\ Altair Benedito Moreira ${ }^{1} \cdot$ Odair Pastor Ferreira ${ }^{2}$
}

Received: 4 April 2016/Accepted: 16 August 2016/Published online: 24 August 2016

(C) Springer Science+Business Media Dordrecht 2016

\begin{abstract}
Purpose Sugarcane bagasse and vinasse are wastes generated at large scales by the Brazilian sugarcane industry. Therefore, new waste treatment and management practices are essential for a sustainable industrial growth and here we purpose the hydrothermal carbonization (HTC) to converts wet biomass into carbon-based solids.

Methods HTC of a mixture of sugarcane bagasse and vinasse was conducted at different temperatures, reaction times and phosphoric acid percentages. The chemical, structural and morphological properties of the hydrochars were evaluated by elemental analysis (CHNS), nutrient quantification $(\mathrm{P}, \mathrm{Ca}, \mathrm{Mg}, \mathrm{K})$, Fourier transform infrared spectroscopy (FTIR), X-ray diffraction (XRD) and scanning electron microscopy (SEM).

Results In the presence of phosphoric acid, the hydrochar yield increased as the ash content increased due to phos-
\end{abstract}

phate precipitates, as observed by XRD. The yield of the hydrochar decreased and the carbon and nitrogen content increased when the temperature increased from 180 to $230{ }^{\circ} \mathrm{C}$. Hydrochars are amorphous and compositionally similar to lignites. The FTIR spectra showed bands at approximately 1700 and $1600 \mathrm{~cm}^{-1}$ in the hydrochar due to carboxylation and aromatization of the products, respectively. The presence of carboxylic acids is important due to their ability to interact with cations and hydrophilic molecules. Additionally, nutrients such as $\mathrm{P}, \mathrm{N}, \mathrm{K}, \mathrm{Ca}$, and $\mathrm{Mg}$ were concentrated in the hydrochar as inorganic phases.

Conclusions HTC applied to sugarcane bagasse and vinasse wastes produces hydrochars primarily containing carbon, nitrogen, and other nutrients as inorganic phases. Hydrochars could potentially be used as an agricultural fertilizer.
Electronic supplementary material The online version of this article (doi:10.1007/s12649-016-9664-4) contains supplementary material, which is available to authorized users.

\section{Odair Pastor Ferreira}

opferreira@fisica.ufc.br

1 Laboratório de Estudos em Ciências Ambientais, Departamento de Química e Ciências Ambientais, Instituto de Biociências, Letras e Ciências Exatas, UNESP, Univ Estadual Paulista, Campus São José do Rio Preto, Cristóvão Colombo, 2265, São José do Rio Preto, São Paulo State 15054-000, Brazil

2 LaMFA - Laboratório de Materiais Funcionais Avançados, Departamento de Física, Universidade Federal do Ceará, P.O. Box 6030, Fortaleza, Ceará 60455-900, Brazil 


\section{Graphical Abstract}

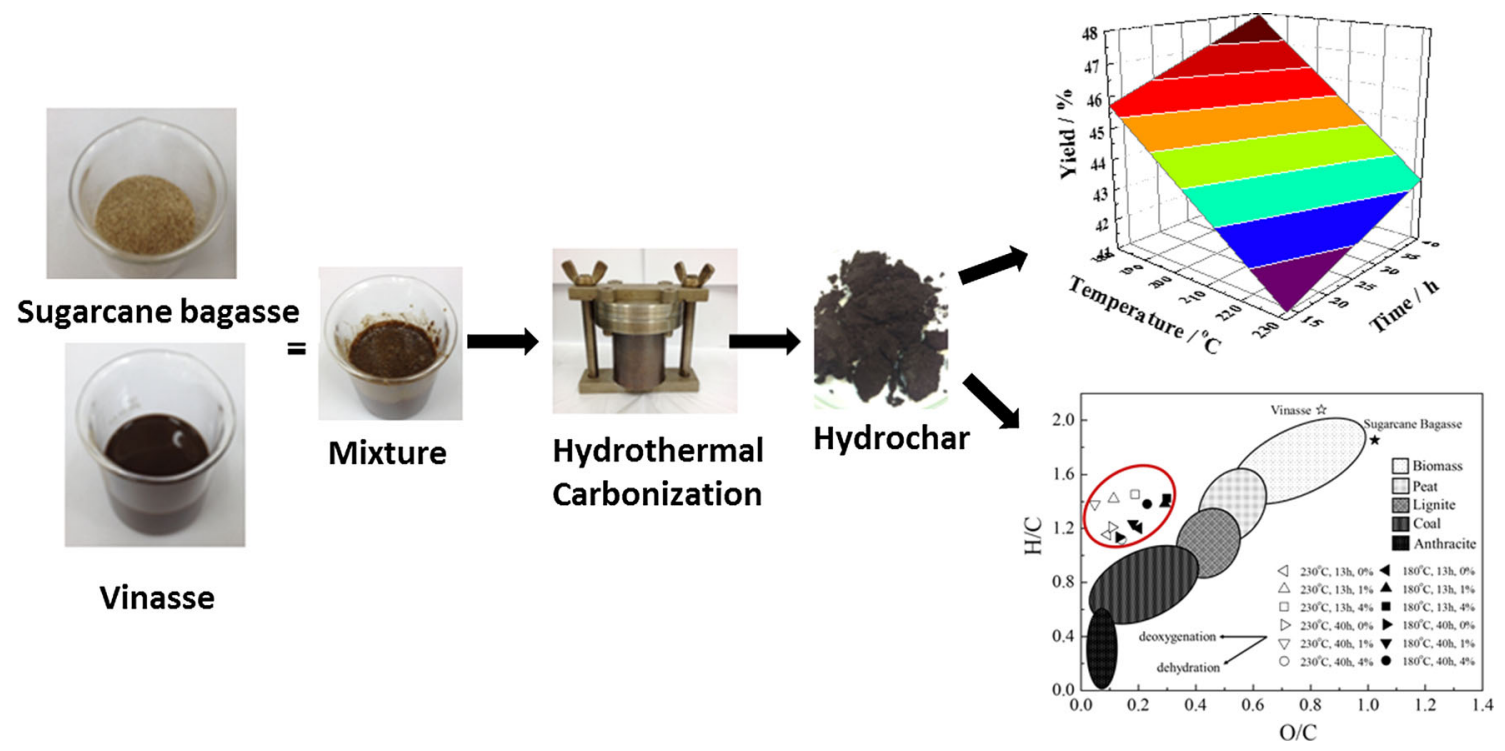

Keywords Hydrothermal carbonization - Sugarcane bagasse $\cdot$ Vinasse $\cdot$ Phosphoric acid

\section{Introduction}

As one of the world's largest producers of ethanol from sugarcane, Brazil's sugarcane industry faces a major environmental problem due to the generation of millions of liters of vinasse (approximately $13 \mathrm{~L}$ of vinasse for every liter of ethanol) and tons of sugarcane bagasse (approximately $280 \mathrm{~kg}$ of sugarcane bagasse for every ton of sugarcane) [1]. Vinasse is a liquid effluent that is rich in organic matter (organic carbon $42-85 \mathrm{~g} \mathrm{~L}^{-1}$ ) and contains large amounts of anions and cations, such as nitrate $\left(0.1-1.2 \mathrm{~g} \mathrm{~L}^{-1}\right)$, sulfate $\left(1.1-4.2 \mathrm{~g} \mathrm{~L}^{-1}\right)$ and potassium (2.3-5.1 $\left.\mathrm{g} \mathrm{L}^{-1}\right)$, among others [2]. Currently, vinasse is employed in a practice called fertiirrigation (vinasse application to soils), which can cause, over time, contamination problems in surface and groundwater if widely applied due the rapid availability of nutrients [3]. Even with fertiirrigation, the stored volume of vinasse is enormous, and the biological and chemical treatments are economically unfeasible. In some cases, vinasse has been concentrated in the sugarcane industry by an evaporation process to reuse the water and to facilitate the use of the concentrated vinasse containing inorganic salts and organic matter. Sugarcane bagasse is the residue generated after the grinding process and primarily consists of cellulose (from 26.6 to $54.3 \%$ ), hemicellulose (from 14.3 to $24.4 \%$ ) and lignin (from 22.7 to $29.7 \%$ ) [4]. This residue is used by industries in energy cogeneration by burning it in boilers, and this energy is consumed by the industry itself or, in some cases, sold to energy distribution companies. However, there is a substantial amount of sugarcane bagasse stored by industries. Thus, sugarcane bagasse and vinasse wastes must be submitted to a more environmental friendly treatment than the traditional treatments and one that is economically viable, promoting more noble uses.

The process of hydrothermal carbonization (HTC) has been studied as an environmentally and sustainable alternative for the conversion of different types of biomass and other wastes (dry or wet) to a solid product that is rich in carbon called hydrochar [5, 6]. Depending on the physicochemical characteristics of the hydrochar, its application has been diverse, for example, to generate energy (fuel), to remove organic and inorganic contaminants, and to use as a soil amendment [7-10]. HTC has advantages over other thermal conversion processes, such as pyrolysis. First, it is a unique process that allows the use of a wet biomass or wastes (moisture above than $60 \%$ ), circumventing the energy expenditure in a drying step. Second, the working temperatures are milder at approximately $150-350{ }^{\circ} \mathrm{C}$, with low input energy requirements. Finally, most of the carbon is incorporated into the hydrochar, minimizing the production of greenhouse gases, such as $\mathrm{CO}_{2}$ and $\mathrm{CH}_{4}$, and bio-oils [5].

The hydrochar formed in HTC is derived from a series of hydrolysis, dehydration, and/or elimination reactions of oxygen functional groups, as well as condensation reactions. These reactions are influenced by different factors, such as temperature, time, $\mathrm{pH}$ of the aqueous medium, the presence of catalysts and, primarily, by the biomass source [11, 12]. Several HTC studies using different types of biomasses have been conducted to understand the physicochemical properties and the mechanisms involved in the 
Table 1 The $\mathrm{pH}$ values and the proximate and ultimate analysis in vinasse and sugarcane bagasse wastes and in hydrochars produced in HTC from the mixture of sugarcane bagasse and vinasse

\begin{tabular}{|c|c|c|c|c|c|c|c|c|c|c|}
\hline Samples & $\mathrm{pH}$ & $\begin{array}{l}\text { Moisture } \\
(\%)\end{array}$ & $\begin{array}{l}\text { Volatile } \\
\text { matter }(\%)\end{array}$ & $\begin{array}{l}\text { Fixed C } \\
(\%)^{\mathrm{a}}\end{array}$ & Ash $(\%)$ & $\mathrm{C}(\%)$ & $\mathrm{H}(\%)$ & $\mathrm{N}(\%)$ & $\mathrm{S}(\%)$ & $\mathrm{O}^{\mathrm{b}}(\%)$ \\
\hline Vinasse (dry) & 4.61 & 10.00 & 80.60 & 48.81 & 19.40 & 35.21 & 6.10 & 2.99 & 0.94 & 39.33 \\
\hline Sugarcane bagasse & 5.05 & 4.65 & 93.51 & 17.64 & 6.49 & 37.20 & 5.75 & $-^{\mathrm{c}}$ & $-^{\mathrm{c}}$ & 50.80 \\
\hline $\mathrm{RI}\left(180^{\circ} \mathrm{C} ; 13 \mathrm{~h} ; 0 \%\right)$ & 4.97 & 2.59 & 89.82 & 22.96 & 10.18 & 60.53 & 6.06 & 4.60 & 2.40 & 16.23 \\
\hline $\mathrm{R} 1\left(180{ }^{\circ} \mathrm{C} ; 13 \mathrm{~h} ; 1 \%\right)$ & 4.29 & 1.97 & 84.62 & 32.74 & 15.38 & 54.35 & 6.27 & 3.30 & 0.23 & 21.19 \\
\hline $\mathrm{R} 2\left(180^{\circ} \mathrm{C} ; 13 \mathrm{~h} ; 4 \%\right)$ & 3.27 & 2.26 & 88.60 & 25.05 & 11.40 & 57.02 & 6.77 & 3.15 & 0.23 & 22.73 \\
\hline RII $\left(180{ }^{\circ} \mathrm{C} ; 40 \mathrm{~h} ; 0 \%\right)$ & 4.62 & 1.77 & 89.19 & 23.39 & 10.81 & 64.72 & 6.12 & 4.97 & 1.98 & 11.40 \\
\hline $\mathrm{R} 3\left(180^{\circ} \mathrm{C} ; 40 \mathrm{~h} ; 1 \%\right)$ & 3.71 & 1.71 & 82.96 & 35.79 & 17.04 & 56.58 & 6.51 & 3.21 & 0.22 & 17.37 \\
\hline $\mathrm{R} 4\left(180^{\circ} \mathrm{C} ; 40 \mathrm{~h} ; 4 \%\right)$ & 3.29 & 1.90 & 85.26 & 31.38 & 14.74 & 60.71 & 6.25 & 3.31 & 0.26 & 14.61 \\
\hline RIII $\left(230{ }^{\circ} \mathrm{C} ; 13 \mathrm{~h} ; 0 \%\right)$ & 5.11 & 1.39 & 88.32 & 24.76 & 11.68 & 66.47 & 6.40 & 5.11 & 2.19 & 8.15 \\
\hline $\mathrm{R} 5\left(230^{\circ} \mathrm{C} ; 13 \mathrm{~h} ; 1 \%\right)$ & 4.83 & 1.82 & 77.52 & 46.78 & 22.48 & 61.20 & 7.25 & 3.99 & 0.19 & 9.27 \\
\hline R6 $\left(230^{\circ} \mathrm{C} ; 13 \mathrm{~h} ; 4 \%\right)$ & 3.54 & 1.83 & 75.61 & 50.61 & 24.39 & 58.20 & 7.05 & 3.54 & 0.17 & 14.64 \\
\hline $\operatorname{RIV}\left(230{ }^{\circ} \mathrm{C} ; 40 \mathrm{~h} ; 0 \%\right)$ & 4.79 & 3.72 & 91.55 & 20.63 & 8.45 & 68.40 & 6.89 & 4.93 & 1.52 & 9.81 \\
\hline $\mathrm{R} 7\left(230^{\circ} \mathrm{C} ; 40 \mathrm{~h} ; 1 \%\right)$ & 4.81 & 1.56 & 73.28 & 55.00 & 26.72 & 62.23 & 7.16 & 4.04 & 0.18 & 7.50 \\
\hline $\mathrm{R} 8\left(230{ }^{\circ} \mathrm{C} ; 40 \mathrm{~h} ; 4 \%\right)$ & 3.53 & 1.60 & 77.25 & 47.10 & 22.75 & 59.15 & 5.51 & 3.04 & 0.23 & 11.14 \\
\hline
\end{tabular}

${ }^{\text {a }}$ Fixed $\mathrm{C}=100-($ volatile matter content - ash content - moisture content $)$

${ }^{\mathrm{b}} \mathrm{O}=100-(\mathrm{C}+\mathrm{H}+\mathrm{N}+\mathrm{S}+\mathrm{ash})$

${ }^{\mathrm{c}}$ Undetectable

Average results are shown for replicate experiments $(\mathrm{n}=2)$ and analysis $(\mathrm{n}=3)$

Relative standard deviation $=5 \%$

conversion process $[6,13]$. There is a consensus in all studies that HTC has a great potential to add value to biomass or biomass wastes, and it has a wide application range.

Few studies have approached the preparation of hydrochar using biomass from the sugarcane industry [14, 15]. Chen et al. [14] used sugarcane bagasse with $39 \%$ (wt $\%$ ) of $\mathrm{C}$ (homogenized in water and dilute sulfuric acid) in the hydrothermal process associated with microwave heating. These authors observed significant changes in the calorific value of the hydrochar produced (20\% enhancement), adding value to the sugarcane bagasse residue for fuel applications. Hoekman et al. [15] used three woody and herbaceous feedstocks, including sugarcane bagasse, in HTC and concluded that the solid hydrochars produced by HTC have an increased energy content that is 20-40\% higher than the raw feedstocks. In both studies, temperature is an important variable in the HTC of lignocellulosic feedstock.

The motivation of this study was to employ a mixture of sugarcane bagasse and vinasse wastes (generated at large scales in the sugarcane industry and containing high concentrations of organic matter and macronutrients such as $\mathrm{N}$, $\mathrm{Ca}$, K, among others), along with phosphoric acid, in the HTC process with two goals: (1) to use phosphoric acid as the catalyst of the HTC process (in contrast to other studies that primarily use strong acids) and (2) to increase the $\mathrm{P}$ and nutrient content in the final product. Additionally, to verify the phosphoric acid effect, HTC reactions were also performed in the absence of the acid. Also, the novelty of this research is the use of vinasse, which allows for the substitution of pure water in the HTC process. Therefore, we propose an environmentally friendly treatment for both wastes, adding value to the final products with a possible future application to soils to improve fertility. Thus, the primary goal of this study was to investigate the hydrochar produced from a mixture of sugarcane bagasse and vinasse using the HTC process under different conditions of temperature, reaction times and phosphoric acid concentrations and to evaluate the chemical and structural properties, focusing on the major essential nutrients.

\section{Materials and Methods}

\section{Feedstock}

Table 1 shows the primary physical and chemical characteristics from both wastes: concentrated vinasse and sugarcane bagasse. Concentrated vinasse (in gallons) was collected after an evaporation step in the sugarcane industry. This raw material was homogenized by stirring before use. Sugarcane bagasse, previously dried at room temperature, was crushed, homogenized and sieved $(<0.5 \mathrm{~mm})$. Phosphoric acid (Merck, $85 \%)$ was employed in the hydrothermal carbonization reactions. 


\section{Hydrothermal Carbonization Process}

The hydrothermal carbonization process was performed in a homemade reactor consisting of a Teflon ${ }^{\circledR} \operatorname{cup}(80-\mathrm{mL}$ maximum capacity) inserted in a stainless steel autoclave to withstand the applied temperatures and pressures. A mixture of the two wastes was used at a ratio of 1:20. In a typical procedure, $3.0 \mathrm{~g}$ of sugarcane bagasse and $60 \mathrm{~mL}$ of pure vinasse or vinasse and phosphoric acid (ranging from 1 to $4 \%(\mathrm{v} / \mathrm{v}))$ were transferred to the Teflon ${ }^{\circledR}$ cup and stirred for $15 \mathrm{~min}$ for homogenization. The initial $\mathrm{pH}$ of the mixtures was measured using a calibrated $\mathrm{pH}$ meter (Marconi, PA200). Then, the cup was transferred to a stainless steel reactor, which was closed and placed in a muffle furnace with the temperature already stabilized at 180 or $230 \pm 10{ }^{\circ} \mathrm{C}$ (Marconi, MA200). The reactions were conducted without any additional stirring for 13 and $40 \mathrm{~h}$. After the reaction time was reached, the reactor was withdrawn from the muffle furnace and cooled in an ice bath to stop the reaction. Then, the $\mathrm{pH}$ was measured again. Hydrochar was separated from the liquid phase by vacuum filtration and was washed with deionized water until reaching a constant $\mathrm{pH}$ value (3.3-5.0). Then, the hydrochar was dried at $50{ }^{\circ} \mathrm{C}$ until reaching a constant weight.

\section{Characterization Methods}

Dried samples of the hydrochars were weighed to evaluate the yield (dry basis). Yield is an important variable to evaluate the efficiency of the HTC process. The yield was calculated using Eq. 1:

Yield $(\%)=\frac{\text { Hydrochar weight }}{\text { Feedstock weight }} \times 100$

where the feedstock weight is the sum of $3.0 \mathrm{~g}$ of sugarcane bagasse and $60 \mathrm{~mL}$ of vinasse or the sum of $3.0 \mathrm{~g}$ of sugarcane bagasse and $60 \mathrm{~mL}$ of vinasse and phosphoric acid, dried at $105{ }^{\circ} \mathrm{C}$ in an oven until reaching a constant weight. Moisture, volatile matter and ash were determined according to ASTM D1762 [16]. Fixed carbon (FC) was calculated by the following equation: $\mathrm{FC}=100-$ (volatile matter content - ash content - moisture content). To evaluate the $\mathrm{pH}$ of hydrochars, a suspension containing $0.5 \mathrm{~g}$ of the solid and $50 \mathrm{~mL}$ of deionized water was stirred for $24 \mathrm{~h}$, and then, the $\mathrm{pH}$ was measured in the resting solution (EPA 9045D). This measurement is fundamental for agricultural applications [17]. The elemental composition of $\mathrm{C}, \mathrm{H}, \mathrm{N}$ and $\mathrm{S}$ was determined using an elemental analyzer EA1108 (Fisons, USA). The O content was calculated as the difference between the ash and the CHNS elemental compositions [18-20]. The functional groups on the hydrochars were analyzed by Fourier Transform Infrared (FTIR) spectroscopy on a UATR-TWO instrument (Perkin Elmer,
USA) in the spectral range of $4000-400 \mathrm{~cm}^{-1}$, with 20 scans and a resolution of $4 \mathrm{~cm}^{-1}$. X-ray diffraction (XRD) patterns were obtained using a D8 Advanced diffractometer (Bruker, USA), with radiation $\mathrm{K} \alpha$ of $\mathrm{Cu}(\lambda=0.1506 \mathrm{~nm})$, operating at $40 \mathrm{~mA}$ and $40 \mathrm{kV}$, using steps of $0.02^{\circ}$ with a total acquisition time of $1 \mathrm{~s}$ per step. The elemental composition of the hydrochar was also evaluated by energy dispersive X-ray spectroscopy (EDS) using a 150 detector (Oxford Instruments, United Kingdom) coupled to an FEG Quanta 450 scanning electron microscope (FEI Company, Czech Republic). To quantify the primary elements, the hydrochar samples were digested (EPA 3050B) on a hot plate at $95{ }^{\circ} \mathrm{C}$ with concentrated $\mathrm{HNO}_{3}$ (Synth, $65 \%$ ) and $\mathrm{H}_{2} \mathrm{O}_{2}$ (Vetec, $30 \%$ ) [21]. Potassium, calcium and magnesium were quantified by flame atomic absorption spectroscopy (FAAS) using an AA240FS (Varian, USA). Additionally, the phosphorus concentration was determined by the yellow vanadomolybdate method (4500-C) using a 700 Plus spectrophotometer (Fento, Brazil) [22]. The morphology of the products was investigated using SEM images obtained by two microscopes: INSPECT 50 and FEG Quanta 450 (FEI Company, Czech Republic).

\section{Results and Discussion}

The hydrochars had different colors, depending on the temperatures employed in the hydrothermal treatment, with a brown color at $180{ }^{\circ} \mathrm{C}$ (indicating partial carbonization) and a black color at $230{ }^{\circ} \mathrm{C}$ (Fig. S1). In all reactions, when the reactor was opened, a burned coffee odor mixed with a caramelized sugar-like odor was emitted. Other authors have also described a characteristic odor in the hydrothermal carbonization of biomass and different colors of hydrochars [23].

Figure 1 presents the hydrochar yields obtained in the HTC processes from the mixture of sugarcane bagasse and vinasse. Figure 1a, b show the yield response according to the temperatures and reaction times, as well as the temperatures and acidity, respectively. The observed yields ranged from 40 to $48 \%$. The yield increases slightly as the phosphoric acid percentage increase. Phosphoric acid could precipitate inorganic compounds, forming phosphatized solids (see the XRD analysis below), increasing the mass of hydrochar and increasing the yield. The yield decreases as the temperature and reaction time increase. The decrease in the yield as a function of temperature and time is due to the higher conversion of biomass, i.e., a higher carbonization degree [12, 24].

\section{Chemical Properties}

Table 1 lists the hydrochar $\mathrm{pH}$ values, as well as the proximate and ultimate analysis (dry basis) performed on the biomass feedstocks and HTC products. The $\mathrm{pH}$ of the 


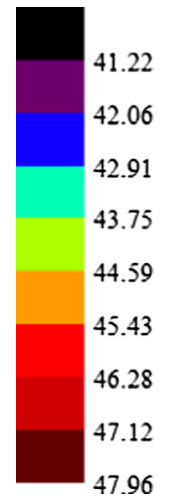

(a)

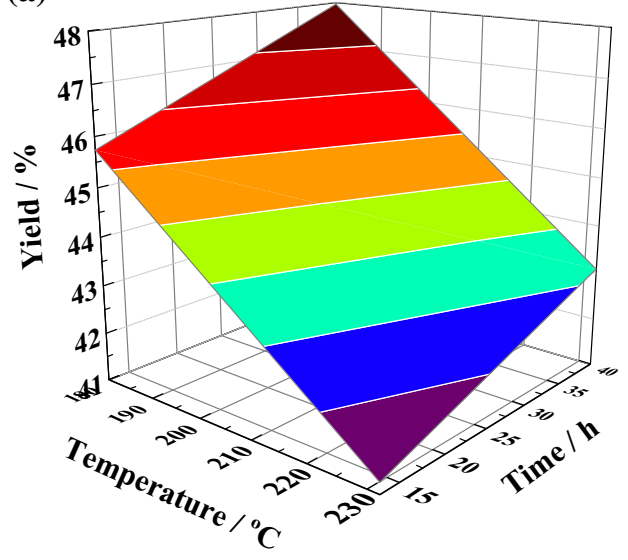

(b)

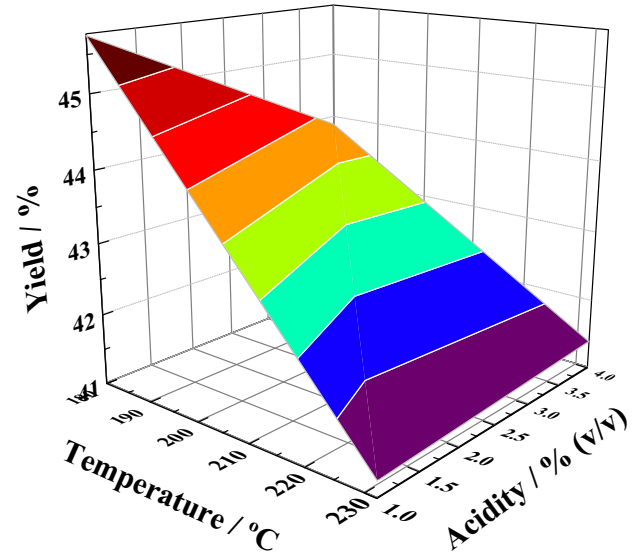

Fig. 1 Yields of hydrochar produced from the mixture of sugarcane bagasse and vinasse as a function of a temperature versus reaction time and b temperature versus acidity

hydrochars is between 5.11 and 3.27. However, in all cases, the $\mathrm{pH}$ of the hydrochars produced from $4 \%(\mathrm{v} / \mathrm{v})$ of phosphoric acid was lower than the values obtained from $1 \%$ of phosphoric acid. Furthermore, the hydrochars prepared with phosphoric acid showed $\mathrm{pH}$ values lower than those obtained in the absence of the acid. These $\mathrm{pH}$ values could be attributed to the partial dissociation of carboxylic acid groups on the external surface and/or in the pores of the hydrochars, which gives them a slightly acidic characteristic. According to the FTIR spectra, carboxylic acid groups are present in the hydrochars produced mainly in the presence of phosphoric acid (see data below). Thus, the lower $\mathrm{pH}$ value of the hydrochars obtained from $4 \%$ acid would be due to a higher degree of oxidation in these materials with a consequent increase in the number of carboxylic acid groups. Xu et al. [25] obtained a hydrochar using macroalgae during HTC with a low $\mathrm{pH}$ (4.1) and associated it with acidic phenolic groups observed in the FTIR spectra. This characteristic of the hydrochar can be important because the major nutrients are soluble at a lower $\mathrm{pH}$, including $\mathrm{P}$ that is available in ultisol, for example, at a $\mathrm{pH}$ of approximately 4.5 , and when the $\mathrm{pH}$ increases to 6.0, the sorption decreases by $34 \%$ [26].

Concentrated vinasse has an ash content of $15 \%$, which is considered high and is comparable to that in sewage sludge samples containing a high load of minerals [20,27]. Sugarcane bagasse is unique due to its volatile matter content, as it is composed of cellulose, hemicellulose and lignin. Typically, in HTC, when the biomass is converted to hydrochar, the volatile matter content decreases due to dehydration and deoxygenation reactions, while the ash content remains constant or increases [28]. The hydrochars produced without phosphoric acid have a moisture content that is lower than that in sugarcane bagasse, while the volatile matter content is similar (Table 1). However, the hydrochars produced in the presence of phosphoric acid have a volatile matter content that is lower and a fixed carbon content that is higher than those in the hydrochars produced without phosphoric acid. The moisture content from both hydrochars is of the same order of magnitude. Thus, the phosphoric acid acts to convert the volatile matter. However, the ash content was increased in the presence of phosphoric acid compared to hydrochar produced without the acid. This result indicates that inorganic matter is precipitated as oxide or phosphate solids (confirmed by the XRD and EDS analysis below). The moisture and volatile matter contents of all hydrochars were decreased, while the ash and fixed carbon contents were increased by increasing the temperature $\left(230^{\circ} \mathrm{C}\right)$ and reaction time $(40 \mathrm{~h})$, as expected. By increasing the temperature and reaction time, the dehydration and deoxygenation processes are more intense, and the precipitated phases have a longer time to form.

Compared with the HTC of pure cellulose and lignin in water [20], a similar behavior was observed for volatile matter and ash content. However, both percentages were markedly higher for the hydrochar in the present study using sugarcane bagasse and vinasse wastes. Thus, the volatile matter of hydrochar in this study was always higher than $72 \%$, and ash was higher than $10 \%$. These values are higher than those in other hydrochars obtained with different lignocellulosic feedstock [29]. However, compared with studies that employed sewage sludge in the HTC, the volatile matter and ash contents are on the same order of magnitude [27]. The percentages of volatile matter and ash content observed in this study indicate that hydrochars contain both organic and inorganic fractions, which is highly significant and interesting for the direction 
of future applications, for example, as a fertilizer. The high inorganic fraction present in the hydrochars is the primary benefits to use vinasse in this study.

The HTC process of biomass leads to a solid enriched in $\mathrm{C}$ and with low levels of $\mathrm{O}$ and $\mathrm{H}$ [28]. When pure cellulose, lignin or wood were used, hydrochars were observed with a higher carbonization degree, consequently with a more pronounced difference among the $\mathrm{C}, \mathrm{O}$ and $\mathrm{H}$ contents compared with hydrochars produced in this study [20]. However, when wastes such as sewage sludge and agricultural residues were used in the HTC, the difference in the $\mathrm{C}, \mathrm{O}$ and $\mathrm{H}$ contents is smaller, suggesting a lower carbonization degree [27, 30]. Thus, the biomass used in the HTC process could directly influence the carbonization degree, represented by the composition of $\mathrm{C}, \mathrm{H}$ and $\mathrm{O}$ in the hydrochar.

For hydrochars produced without phosphoric acid, the $\mathrm{C}$ content was higher and the $\mathrm{H}$ and $\mathrm{O}$ contents were lower than those in hydrochars produced in the presence of phosphoric acid (Table 1). This behavior suggests that phosphoric acid acts mainly to precipitate inorganic compounds and does not effectively convert or carbonize the biomass (precipitation of inorganic phases was confirmed by the XRD results), as the ash values are higher for hydrochars produced under these conditions. The $\mathrm{N}$ and $\mathrm{S}$ contents in hydrochars tend to decrease in the presence of phosphoric acid. Nitrogen appears to dissolve in the aqueous phase in the presence of phosphoric acid. The sulfur content in the hydrochars without phosphoric acid has an expressive value compared to hydrochars with phosphoric acid. Sulfur comes from vinasse and remains only in hydrochars without phosphoric acid, most likely as sulfate inorganic solids. It appears that the sulfate remains in the aqueous phase in the reactions with phosphoric acid, possibly due to the formation of other inorganic solids as phosphates, which generally have lower solubilities than sulfates. The carbon content increases as the temperature and reaction time increases, while in contrast, the $\mathrm{O}$ content decreases. Thus, the temperature and reaction time promote the biomass conversion, resulting in a higher carbonization degree. The nitrogen content slightly increases, and the sulfur content decreases as the temperature increases. He et al. [23] observed that $2.2 \%$ of nitrogen and $3.9 \%$ of sulfur remained in the hydrochar when sewage sludge was hydrothermally carbonized at $200{ }^{\circ} \mathrm{C}$ from 4 to $12 \mathrm{~h}$. Other authors found that the $\mathrm{N}$ and $\mathrm{S}$ contents decreased at high temperatures [31, 32]. When sewage sludge was subjected to liquefaction at $100-300{ }^{\circ} \mathrm{C}$ for $1 \mathrm{~h}$, the $\mathrm{N}$ concentration decreased due to protein degradation (above $150{ }^{\circ} \mathrm{C}$ ) [31]. With respect to $\mathrm{S}$, desulfurization was observed when switchgrass was hydrothermally carbonized at $300{ }^{\circ} \mathrm{C}$ for 30 min [32]. In our case, $\mathrm{N}$ is present mainly as $\mathrm{NO}_{3}{ }^{-}$in vinasse, not as organic-N, such as that present in protein.
As a result, it appears that $\mathrm{N}$ is entrapped in the hydrochar structure, and this behavior is favored at higher temperatures. The decrease of $\mathrm{H}$ and $\mathrm{O}$ in the hydrochars is due to the dehydration and/or deoxygenation reactions of the biomass. Consequently, the increase in $\mathrm{C}$ is explained by the condensation reactions; however, this process is incomplete in our case, considering "char" as a final product because $\mathrm{H}$ is still present.

A van Krevelen diagram was constructed plotting the $\mathrm{H} / \mathrm{C}$ versus $\mathrm{O} / \mathrm{C}$ molar ratios from all hydrochars along with both feedstock biomasses (Fig. 2). The first observation in the graphic is the difference between the $\mathrm{H} / \mathrm{C}$ and $\mathrm{O} / \mathrm{C}$ ratios from the feedstock biomasses and hydrochars. In the hydrochars, these ratios decreased substantially. A smaller $\mathrm{H} / \mathrm{C}$ ratio indicates a more carbonized hydrochar, meaning that more aromatic moieties are present in the carbonaceous materials, thus approaching the composition of coal and anthracite. Furthermore, the $\mathrm{O} / \mathrm{C}$ ratio indicates the gain or loss of oxygenated chemical functions in the hydrochars, and the smaller these values, the more deoxygenated the hydrochars. In general, the hydrochars produced in the absence of $\mathrm{H}_{3} \mathrm{PO}_{4}$ have lower $\mathrm{H} / \mathrm{C}$ and $\mathrm{O} / \mathrm{C}$ ratios than those of hydrochars produced in the presence of $\mathrm{H}_{3} \mathrm{PO}_{4}$. Thus, HTC conducted without phosphoric acid is dominated by a more pronounced deoxygenation and aromatization process. Although all hydrochars produced in the presence of phosphoric acid have almost the same $\mathrm{H} / \mathrm{C}$ ratio (1.3), their $\mathrm{O} / \mathrm{C}$ ratios change from 0.05 to 0.3 . This suggests that phosphoric acid primarily acts to oxidize the hydrochars, rather than dehydrate them. At higher temperatures and reaction times, both $\mathrm{H} / \mathrm{C}$ and $\mathrm{O} / \mathrm{C}$ ratios decreased, showing a better carbonization degree. In general, as the severity of the reaction conditions increases

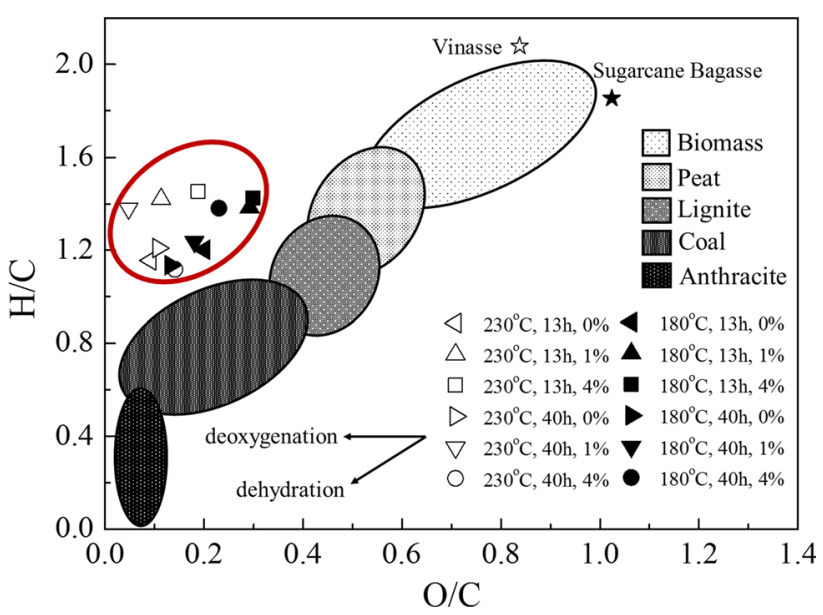

Fig. 2 The van Krevelen diagram for feedstocks of vinasse and sugarcane bagasse and hydrochars. Cellulose, wood, lignin, lignites, coal and anthracite are shown for comparison 
over time in the $\mathrm{HTC}$ process, the $\mathrm{H} / \mathrm{C}$ and $\mathrm{O} / \mathrm{C}$ ratios decrease until reaching ratios similar to coal or anthracite.

In our case, the highest $\mathrm{H} / \mathrm{C}$ and $\mathrm{O} / \mathrm{C}$ molar ratios are observed in the hydrochars. After hydrothermal carbonization was performed, all hydrochars (without and with acid) presented an $\mathrm{H} / \mathrm{C}$ molar ratio between 1.00 and 1.50 , which is close to that of peat and lignites, and an $\mathrm{O} / \mathrm{C}$ molar ratio between 0.05 and 0.3 , which is similar to that of lignites and coal [33]. This behavior was also observed by Basso et al. [19], who produced hydrochar from agro-industrial waste (grape marc) using HTC. These findings are important for the possible future applications of hydrochar because lignites are commonly used as fertilizers to improve soil quality [34].

EDS measurements were used to qualitatively investigate the elements present in the hydrochars (Table S1). First, elements such as $\mathrm{C}, \mathrm{O}, \mathrm{Si}, \mathrm{Ca}, \mathrm{S}$ and $\mathrm{K}$ were detected in the hydrochars produced in the absence of phosphoric acid. Elements such as $\mathrm{C}, \mathrm{O}, \mathrm{Si}, \mathrm{Mg}, \mathrm{Ca}$ and $\mathrm{P}$ were detected in the HTC products obtained in the presence of phosphoric acid (Figs. S2 and S3). This finding confirms the immobilization of $\mathrm{P}$ from phosphoric acid. For all morphologies, the main difference in comparing only the elemental compositions was the presence of $\mathrm{S}$ for hydrochars obtained without phosphoric acid, while $\mathrm{P}$ was observed for reactions performed in the presence of the acid. These data are in agreement with the elemental CHNS analysis (Table 1), which indicated a higher content of $\mathrm{S}$ for hydrochars prepared using only vinasse and sugarcane bagasse. The finding suggests the occurrence of a precipitation reaction between sulfate and cations (such as $\mathrm{Ca}$ ) from vinasse when the reactions were conducted without acid. Meanwhile, when the reactions were performed with phosphoric acid, phosphate salts could have been precipitated (for more details, see the XRD section).

Therefore, to improve the identification of the major elements in the hydrochars produced in the presence of phosphoric acid, even at low concentrations, EDS spectra were measured of ashes obtained after calcination. Thus, it was possible to confirm the presence of the following elements in the hydrochars produced with acid: $\mathrm{P}, \mathrm{Ca}, \mathrm{Mg}$, $\mathrm{K}, \mathrm{Fe}$ and $\mathrm{Si}$ (Table $\mathrm{S} 1$ ). Because $\mathrm{Ca}, \mathrm{K}, \mathrm{Mg}$ and $\mathrm{P}$ are considered macronutrients, these elements were determined quantitatively. Table 2 provides the concentrations of $\mathrm{K}, \mathrm{P}, \mathrm{Ca}$ and $\mathrm{Mg}$ in the feedstocks and hydrochars. It is evident that all elements were concentrated in the hydrochars compared with the initial sugarcane bagasse, except for $\mathrm{P}$ and $\mathrm{K}$ in the hydrochars produced using only vinasse and sugarcane bagasse. In addition, there are significant differences in the $\mathrm{P}, \mathrm{K}$ and $\mathrm{Mg}$ concentrations when the reactions were conducted using phosphoric acid. These hydrochars showed a much higher concentration of $\mathrm{P}, \mathrm{K}$ and $\mathrm{Mg}$ compared to those prepared without acid, mainly at $230{ }^{\circ} \mathrm{C}$. It is possible that $\mathrm{K}$ and $\mathrm{Mg}$ are precipitated as struvite $\mathrm{K}\left(\mathrm{MgKPO}_{4} \cdot 6 \mathrm{H}_{2} \mathrm{O}\right)$ when phosphoric acid is present [35]. Although the precipitation of struvite occurs at a higher $\mathrm{pH}$, the temperature appears to substantially contribute to the immobilization of these nutrients in the hydrochars. The $\mathrm{Ca}$ concentration is similar or slightly lower for the hydrochars prepared in the presence of the acid. Thus, these observations provide further evidence of precipitation reactions between phosphate from phosphoric acid and cations such as $\mathrm{K}, \mathrm{Ca}$ and $\mathrm{Mg}$ from vinasse when the reactions are performed in the presence of acid and between $\mathrm{Ca}$ and sulfate when the reactions are performed in the absence of acid.

Table 2 Phosphorus $(\mathrm{P})$, potassium $(\mathrm{K})$, calcium $(\mathrm{Ca})$ and magnesium $(\mathrm{Mg})$ concentrations in vinasse, sugarcane bagasse and hydrochars

\begin{tabular}{|c|c|c|c|c|}
\hline Sample & $\mathrm{P}\left(\mathrm{g} \mathrm{kg}^{-1}\right)$ & $\mathrm{K}\left(\mathrm{g} \mathrm{kg}^{-1}\right)$ & $\mathrm{Ca}\left(\mathrm{g} \mathrm{kg}^{-1}\right)$ & $\operatorname{Mg}\left(\mathrm{g} \mathrm{kg}^{-1}\right)$ \\
\hline Vinasse (in $\mathrm{g} \mathrm{L}^{-1}$ ) & 0.7 & 21.7 & 2.7 & 1.2 \\
\hline Sugarcane bagasse & 1.7 & 1.9 & 1.1 & 0.7 \\
\hline $\mathrm{RI}\left(180^{\circ} \mathrm{C} ; 13 \mathrm{~h} ; 0 \%\right)$ & 0.2 & 1.2 & 14.9 & 2.6 \\
\hline $\mathrm{R} 1\left(180{ }^{\circ} \mathrm{C} ; 13 \mathrm{~h} ; 1 \%\right)$ & 17.0 & 3.3 & 18.8 & 7.1 \\
\hline $\mathrm{R} 2\left(180{ }^{\circ} \mathrm{C} ; 13 \mathrm{~h} ; 4 \%\right)$ & 10.1 & 3.4 & 4.4 & 3.4 \\
\hline $\mathrm{RII}\left(180^{\circ} \mathrm{C} ; 40 \mathrm{~h} ; 0 \%\right)$ & 0.4 & 0.9 & 13.9 & 2.9 \\
\hline $\mathrm{R} 3\left(180{ }^{\circ} \mathrm{C} ; 40 \mathrm{~h} ; 1 \%\right)$ & 21.7 & 3.0 & 13.1 & 14.1 \\
\hline $\mathrm{R} 4\left(180{ }^{\circ} \mathrm{C} ; 40 \mathrm{~h} ; 4 \%\right)$ & 40.2 & 2.8 & 11.0 & 13.3 \\
\hline RIII $\left(230{ }^{\circ} \mathrm{C} ; 13 \mathrm{~h} ; 0 \%\right)$ & 0.3 & 0.9 & 14.3 & 2.9 \\
\hline $\mathrm{R} 5\left(230{ }^{\circ} \mathrm{C} ; 13 \mathrm{~h} ; 1 \%\right)$ & 24.3 & 6.9 & 27.0 & 10.7 \\
\hline $\mathrm{R} 6\left(230{ }^{\circ} \mathrm{C} ; 13 \mathrm{~h} ; 4 \%\right)$ & 21.1 & 12.6 & 8.1 & 12.9 \\
\hline $\operatorname{RIV}\left(230{ }^{\circ} \mathrm{C} ; 40 \mathrm{~h} ; 0 \%\right)$ & 0.3 & 0.7 & 22.2 & 6.0 \\
\hline $\mathrm{R} 7\left(230{ }^{\circ} \mathrm{C} ; 40 \mathrm{~h} ; 1 \%\right)$ & 28.0 & 9.9 & 29.0 & 16.8 \\
\hline $\mathrm{R} 8\left(230{ }^{\circ} \mathrm{C} ; 40 \mathrm{~h} ; 4 \%\right)$ & 32.8 & 19.1 & 13.9 & 18.3 \\
\hline
\end{tabular}

Average results are shown for replicate experiments $(\mathrm{n}=2)$ and analysis $(\mathrm{n}=3)$. Relative standard deviation $=10 \%$ 
Therefore, using the HTC process, the main elements from vinasse and phosphoric acid can be concentrated in the hydrochar. The mass balance shows that approximately $40 \%$ of $\mathrm{P}$ added in the HTC remains in the hydrochars, while approximately $90 \%$ of $\mathrm{Ca}$ and $\mathrm{Mg}$ is immobilized. At $230{ }^{\circ} \mathrm{C}$ and $40 \mathrm{~h}$, the nutrient concentrations reach the maximum values, increasing 25 times for $\mathrm{P}, \mathrm{Ca}$ and $\mathrm{Mg}$ and 10 times for $\mathrm{K}$ compared with those at $180{ }^{\circ} \mathrm{C}$ and $13 \mathrm{~h}$. Additionally, acidity can influence the nutrient concentrations; in the case of $\mathrm{Ca}$, in all reactions with $4 \%$ of phosphoric acid, the concentration decreased 2.5 times compared with reactions using $1 \%$ of phosphoric acid. For $\mathrm{P}$, the hydrochars obtained from the reactions performed with $4 \%$ of acid and $40 \mathrm{~h}$ contain more phosphorus than that contained from the reactions performed with $1 \%$ of acid and $13 \mathrm{~h}$. This behavior suggests that it is possible to

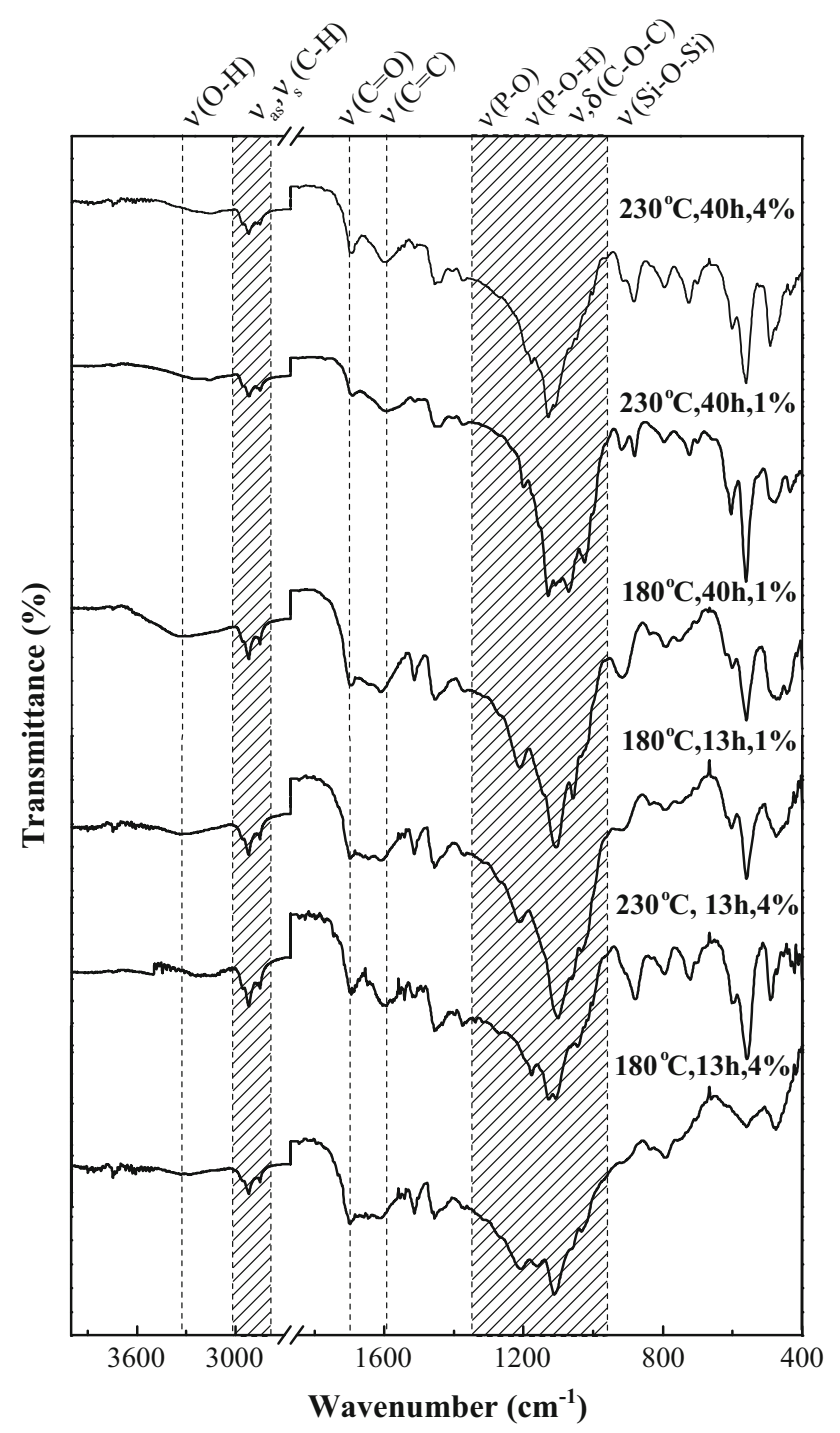

Fig. 3 FTIR spectra of hydrochars produced in the presence of phosphoric acid produce a hydrochar with specific characteristics, depending on the proposed use.

\section{Structural and Morphological Properties}

For a better interpretation of the effect of the employed reaction parameters on the structure and morphology of the produced hydrochars, FTIR, XRD and SEM studies were performed.

The FTIR spectra of the hydrochars and feedstocks are shown in Figs. 3, S4 and S5, respectively. The sugarcane bagasse and vinasse wastes are composed of a complex blend of substances, making an exact assignment of all bands present in the FTIR spectra of these raw materials very difficult (Fig. S4). However, in general, it was possible to identify chemical groups such as $\mathrm{O}-\mathrm{H}$ (large bands at $3400-3000 \mathrm{~cm}^{-1}$ attributed to the $\mathrm{O}-\mathrm{H}$ stretching mode), $\mathrm{C}-\mathrm{H}$ (bands at 2900 and $2850 \mathrm{~cm}^{-1}$ and at $1400-1200 \mathrm{~cm}^{-1}$ corresponding to asymmetric and symmetric $\mathrm{C}-\mathrm{H}$ stretching modes and $\mathrm{C}-\mathrm{H}$ bending, respectively), and $\mathrm{C}-\mathrm{O}-\mathrm{C}$ (an intense, large band between 1200 and $950 \mathrm{~cm}^{-1}$ attributed mainly to the vibrations of polysaccharide chains) that are characteristic of cellulose, hemicellulose and lignin present in sugarcane bagasse and other organic compounds in vinasse [36]. Groups such as $\mathrm{C}=\mathrm{O}$ (band at $1735 \mathrm{~cm}^{-1}$ attributed to the stretching mode of carbonyl in ester compounds) and $\mathrm{C}=\mathrm{C}$ (band at $1635 \mathrm{~cm}^{-1}$ corresponding to the $\mathrm{C}=\mathrm{C}$ vibration mode of aromatic rings) characteristic of lignin were also found in sugarcane bagasse. Note that the large and intense band between 1200 and $950 \mathrm{~cm}^{-1}$ centered at $1035 \mathrm{~cm}^{-1}$ in the FTIR spectrum of sugarcane bagasse may also have contributions from $\mathrm{Si}-\mathrm{O}-\mathrm{Si}$ stretching modes $[37,38]$. The presence of $\mathrm{SiO}_{2}$ in this waste was confirmed by the XRD measurements (Fig. S6). In addition, for the FTIR spectrum of dry vinasse, the large and intense band centered at $1035 \mathrm{~cm}^{-1}$ arises from contributions from $\mathrm{C}-\mathrm{O}-\mathrm{C}$ vibrations of organic compounds, and this large band may also have contributions from the $\mathrm{S}-\mathrm{O}$ vibration modes of sulfate ions. The presence of this anion was also confirmed by XRD measurements (Fig. S6). Furthermore, the band at $1395 \mathrm{~cm}^{-1}$ in the FTIR spectrum of vinasse may be attributed to $\mathrm{NO}_{3}{ }^{-}$vibration modes.

In general, in the FTIR spectra of hydrochars, a decrease is expected in the intensity of the bands related to the $\mathrm{O}-\mathrm{H}$, $\mathrm{C}-\mathrm{H}, \mathrm{C}-\mathrm{O}$ and $\mathrm{C}-\mathrm{O}-\mathrm{C}$ vibration modes due to dehydration and deoxygenation reactions of biomass during hydrothermal carbonization. This behavior was observed by comparing the spectral profiles of hydrochars to those of raw materials (Figs. 3, S4 and S5). In addition, the spectral profiles from both hydrochars produced in the presence and absence of acid were similar, showing typical bands of these carbonaceous materials. However, in the spectral 
range that can contain the contribution of inorganic compounds (below $1250 \mathrm{~cm}^{-1}$ ), the infrared spectra of the hydrochars produced without and with phosphoric acid showed distinct results.

More specifically, it is possible to observe a drastic decrease in the intensity of the large band attributed to the O-H stretching mode at $3400-3000 \mathrm{~cm}^{-1}$ in all FTIR spectra from both hydrochars prepared with (Fig. 3) and without (Fig. S5) phosphoric acid, suggesting the elimination of hydroxyl groups. However, the spectrum of the sample produced at $180{ }^{\circ} \mathrm{C}$ and $13 \mathrm{~h}$ (without acid) showed a more intense $\mathrm{O}-\mathrm{H}$ band, indicating, in this case, a lower carbonization degree. Bands at approximately 2955, 2918 and $2849 \mathrm{~cm}^{-1}$ corresponding to asymmetric and symmetric $\mathrm{C}-\mathrm{H}$ stretching modes (in $-\mathrm{CH}_{3}$ and $-\mathrm{CH}_{2}$ groups) can be observed in all FTIR spectra. Thus, although there was a decreased number of $\mathrm{O}-\mathrm{H}$ groups in the hydrochars, the permanence of the $\mathrm{C}-\mathrm{H}$ bands indicates incomplete carbonization, corroborating the results from the CHNS elemental analysis (Table 1). Furthermore, in all hydrochars, the new bands at $1700 \mathrm{~cm}^{-1}$ can be attributed to the $\mathrm{C}=\mathrm{O}$ stretching vibrations of carboxylic acid. These functional groups could be formed due to the oxidation of superficial carbon in contact with the acid reaction medium. Additionally, the new broad and asymmetric bands in the range of $1610-1590 \mathrm{~cm}^{-1}$ could be attributed to the $\mathrm{C}=\mathrm{C}$ group in aromatic rings, revealing the aromatization of the hydrochars. For hydrochars prepared at 230 and $180{ }^{\circ} \mathrm{C}$ with the addition of phosphoric acid (Fig. 3), the $\mathrm{C}=\mathrm{C}$ bands can be observed at 1600 and $1610 \mathrm{~cm}^{-1}$, respectively. For hydrochars prepared without acid, the $\mathrm{C}=\mathrm{C}$ bands are observed at approximately $1590 \mathrm{~cm}^{-1}$. These different frequencies for $\mathrm{C}=\mathrm{C}$ vibrations can represent distinct aromatic moieties in the hydrochars, but for accurate determinations of the nature of these moieties, more specific studies are needed. For hydrochars prepared in the presence of phosphoric acid, at $230{ }^{\circ} \mathrm{C}$, the bands at 1700 and $1600 \mathrm{~cm}^{-1}$ are more pronounced than those at $180{ }^{\circ} \mathrm{C}$ for all hydrochars, indicating a more effective carboxylation and aromatization process. Note that the relative intensities of the bands attributed to $\mathrm{C}=\mathrm{O}$ and $\mathrm{C}=\mathrm{C}$ for hydrochars prepared in phosphoric acid are similar. However, these bands present distinct intensities when the hydrocarbons were prepared without acid, with the $\mathrm{C}=\mathrm{C}$ band being slightly more intense than the $\mathrm{C}=\mathrm{O}$ band. This observation may indicate that the hydrochars prepared in the presence of the phosphoric acid possess a more oxidized surface.

An analysis of the spectral region below $1250 \mathrm{~cm}^{-1}$ (Figs. 3 and S5) clearly reveals changes in the band profiles for hydrochars compared with the initial feedstocks (Figure S4). This spectral region is distinct for hydrochars produced with and without phosphoric acid. However, the band profiles are very complex because they contain information from both carbon chains and inorganic phases in the hydrochars. For example, the large and intense bands between 1250 and $950 \mathrm{~cm}^{-1}$ showing several shoulders (overlap of unresolved bands) could contain contributions from $\mathrm{C}-\mathrm{O}-\mathrm{C}$ vibration modes of the chains present in the hydrochars. Kabyemela et al. [39] also attributed this band to the $\mathrm{C}-\mathrm{O}$ stretching mode and suggested that a decrease in its intensity would be due to the transformation of oxygenated functional groups of biomass during the hydrothermal carbonization. In contrast, $\mathrm{He}$ et al. [23] observed a drastic increase in the relative intensity of the $1030 \mathrm{~cm}^{-1}$ band in the HTC samples and attributed it to the high ash content present as mineral compounds.

In this study, due to the use of $\mathrm{H}_{3} \mathrm{PO}_{4}$ in $\mathrm{HTC}$, a precipitation reaction involving phosphate and cations contained in the vinasse, such as $\mathrm{Ca}^{2+}$ and $\mathrm{Mg}^{2+}$, must have occurred. The XRD measurements confirm the presence of crystalline phosphate phases (Fig. 4). Therefore, the intense band at $1200-1000 \mathrm{~cm}^{-1}$ may also contain contributions of P-O and $\mathrm{P}-\mathrm{O}-\mathrm{H}$ stretching modes from $\mathrm{PO}_{4}{ }^{3-}$ and $\mathrm{HPO}_{4}{ }^{2-}$ units, respectively (Fig. 3). Moreover, bands below $800 \mathrm{~cm}^{-1}$ may also have contributions of other $\mathrm{P}-\mathrm{O}$ vibration modes $[40,41]$. When the reactions were conducted without phosphoric acid, bands were identified in the range from 1170 to $1015 \mathrm{~cm}^{-1}$ associated with the symmetric and asymmetric stretching mode of the $\mathrm{SO}_{4}{ }^{2-}$ anion (Fig. S5). The XRD patterns of these samples indicated the presence of $\mathrm{CaSO}_{4}$ (anhydrite phase, see Fig. S7). Typical bands of sulfate anions can also be observed at 670,617 and $592 \mathrm{~cm}^{-1}$ for all spectra in Fig. S5 [40, 42].

Furthermore, it is possible that the spectral region from 1250 to $950 \mathrm{~cm}^{-1}$ for all hydrochars also have contributions from $\mathrm{Si}-\mathrm{O}-\mathrm{Si}$ vibrations due to the presence of $\mathrm{SiO}_{2}$ [38]. The presence of this compound was also confirmed by the XRD measurements (Figs. 4 and S7).

The XRD patterns for the hydrochars produced in the presence and in the absence of phosphoric acid are shown in Figs. 4 and S7, respectively. Considering the vinasse, after water evaporation occurred at $105{ }^{\circ} \mathrm{C}$, a diffraction profile typical of crystalline compounds was observed whose main peaks can be indexed to $\mathrm{K}_{2} \mathrm{SO}_{4}$ (JCPDS72-0354) and $\mathrm{K}_{3-}$ $\mathrm{Na}\left(\mathrm{SO}_{4}\right)_{2}$ (JCPDS74-1742) (Fig. S6). Additionally, the XRD pattern of sugarcane bagasse presents peaks of crystalline phases primarily indexed to $\mathrm{SiO}_{2}$ (JCPDS82-1576).

For all hydrochars (Figs. 4a, b and S7), the XRD profiles suggest a complex blend of crystalline and amorphous phases, characterized by narrow and intense peaks superimposed on a large and low intensity peak. The large peak observed in all diffractograms of the hydrochars centered between $21^{\circ}$ and $23^{\circ}(2 \theta)$ can be associated with the presence of amorphous carbon (Fig. 4b). Thus, the organic matter present in vinasse and sugarcane bagasse was 
Fig. 4 a XRD patterns of hydrochars produced with phosphoric acid. b A segment of the XRD patterns in the interval of $10^{\circ}-35^{\circ}$ showing the large peak centered at approximately $21^{\circ}-23^{\circ}(2 \theta)$

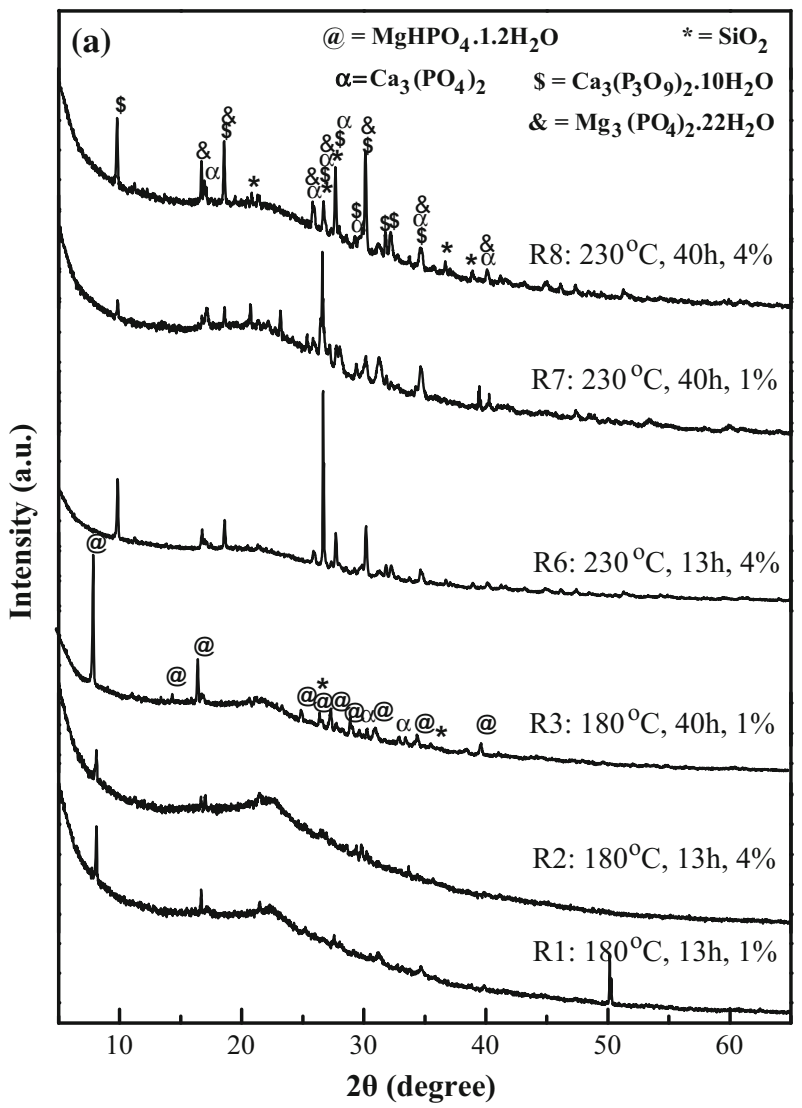

transformed into amorphous carbon. Kang et al. [20] also observed large peaks located between $10^{\circ}$ and $30^{\circ}(2 \theta)$ in the XRD of hydrochars obtained from xylose, lignin and wood and ascribed them to amorphous carbon. Particularly, in $\mathrm{HTC}$ at $180{ }^{\circ} \mathrm{C}$ and $13 \mathrm{~h}$ without phosphoric acid (Fig. S7), it is possible to observe shoulders superimposed on the large peak at $15.6^{\circ}$ and $22.5^{\circ}(2 \theta)$, which can be attributed to cellulose that was not completely transformed into amorphous carbon. This behavior was not evidenced in hydrochars at $180^{\circ} \mathrm{C}$ in the presence of phosphoric acid.

Furthermore, the XRD measurements were used to differentiate the crystalline phases present in hydrochars prepared with and without phosphoric acid, as shown in Figs. 4 and S7, respectively. First, in all case of hydrochars produced in the absence of phosphoric acid, the crystalline phase can be attributed to $\mathrm{CaSO}_{4}$ (anhydrite, JCPDS 37-1496) and $\mathrm{SiO}_{2}$ (JCPDS 05-0490). However, XRD patterns that can be attributed to calcium phosphates, $\mathrm{Ca}_{3}\left(\mathrm{PO}_{4}\right)_{2}$ (JCPDS 70-0364) and $\mathrm{Ca}_{3}\left(\mathrm{P}_{3} \mathrm{O}_{9}\right)_{2} \cdot 10 \mathrm{H}_{2} \mathrm{O}$ (JCPDS 40-0008), magnesium phosphate, $\mathrm{MgHPO}_{4}$. 1.2 $\mathrm{H}_{2} \mathrm{O}$ (JCPDS 49-0752) and $\mathrm{Mg}_{3}\left(\mathrm{PO}_{4}\right)_{2} \cdot 22 \mathrm{H}_{2} \mathrm{O}$ (JCPDS 83-1486), and silicon oxide (JCPDS87-2096 and 88-2487) (Fig. 4a) when the reactions were conducted in the presence of phosphoric acid. It was not possible to identify the struvite $\mathrm{K}$ phase probably due to the complexity of the multiphase diffractograms or because this compound presents as amorphous phase. Thus, it is evident that phosphoric acid is essential for the immobilization of phosphorus in the hydrochars when vinasse is used as the medium to promote hydrothermal carbonization. This process could occur through the precipitation reaction between $\mathrm{Ca}, \mathrm{Mg}$ and $\mathrm{K}$ cations from vinasse/sugarcane bagasse and phosphate from phosphoric acid. The different phosphate phases observed in the products were attributed to the differences in the hydrothermal conditions under which these reactions were performed. In the reactions conducted in the absence of acid, $\mathrm{CaSO}_{4}$ would be formed by the reaction between calcium and sulfate from vinasse/sugarcane bagasse (see Tables 1 and 2 and Fig. S6). These inorganic phases contribute to the high ash content observed in the hydrochars (Table 1). The crystalline phases detected in the XRD measurements are in agreement with the elemental analysis by the EDS of hydrochars and ashes (Table S1).

XRD analyses also indicated that the temperature plays a key role in the formed phosphate phases. The XRD profiles for the hydrochars obtained at $230{ }^{\circ} \mathrm{C}$ are distinct from those obtained at $180{ }^{\circ} \mathrm{C}$, showing that the calcium phosphates and magnesium phosphates formed in each case have different crystalline structures (Fig. 4a). This is an important point because it might represent greater or lesser availability of these elements in future applications, such as 


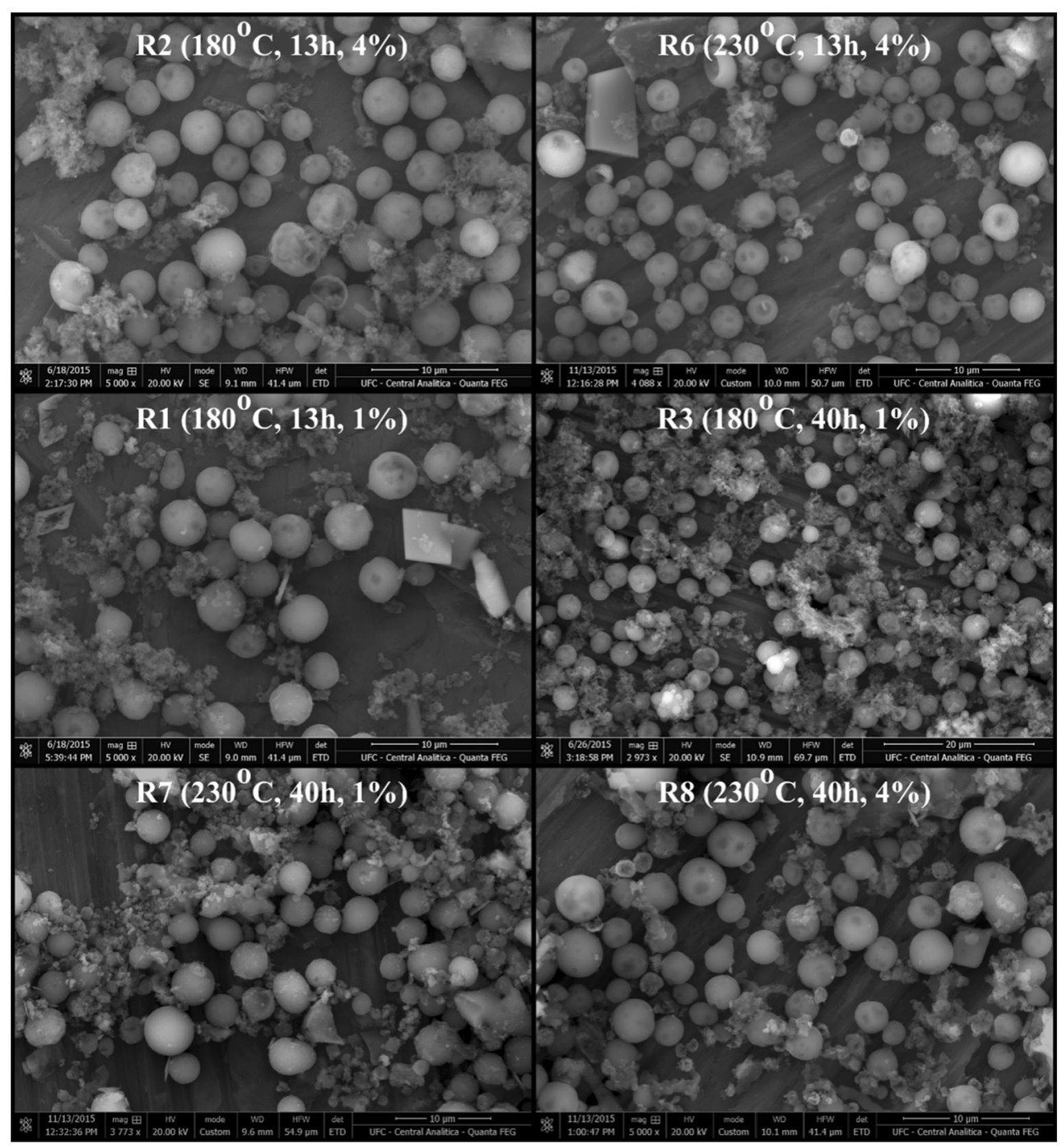

Fig. 5 Scanning electron microscopy (SEM) images of hydrochars produced with phosphoric acid

fertilizer, due to the distinct solubility of the phosphate compounds. Considering the reaction times, it was not possible to identify substantial differences in the diffractograms.

From a morphological perspective, all hydrochars produced in the presence and absence of phosphoric acid showed particles with similar morphologies (spheres, rods, plates and irregular shapes-agglomerates) under different temperatures and reaction times (Figs. 5 and S8). However, the number of spheres observed in the samples produced with acid is greater than that produced without phosphoric acid. Table S1 summarizes the primary morphologies observed in the hydrochars. Specifically, for hydrochars prepared with acid, when the temperature increased to $230{ }^{\circ} \mathrm{C}$, the number of particles with a spherical morphology also increased too. The average diameter of the spheres is approximately $3 \mu \mathrm{m}$. Additionally, the spheres show macrospores on their surface. These pores could be formed because the inorganic phase was expelled during sphere formation. Gao et al. [43] described that nano/micro spheres originate from the decomposition of hemicellulose and cellulose. The literature also suggests that these rough and irregular morphologies can be attributed to less degraded lignin [35]. However, in our case, the irregular morphologies are most likely associated with inorganic phases.

\section{Conclusions}

In this study was performed the hydrothermal carbonization of sugarcane bagasse and vinasse wastes in the presence of phosphoric acid. In the range of the acid concentration used in the hydrothermal experiments, it was not possible to identify a drastic contribution of the acid into carbonization degree of hydrochars. On the other hand, 
the phosphoric acid has key role in the formation of inorganic phase. Considering the hydrochars, these materials have a substantial amount of carbonaceous matter, which is influenced mainly by the temperature. The final reactional acid media promotes the oxidation of superficial carbons to carboxylic acid groups in all treatment performed, but our results suggest that in the presence of phosphoric acid, a more intense oxidation occurred. The presence of this chemical functional group is an important point because of its capacity of interacting with hydrophilic molecules and cations. In addition, carbon and nitrogen contents were increased when the temperature increased from 180 to $230{ }^{\circ} \mathrm{C}$. Hydrochars are structurally amorphous and compositionally similar to lignite materials according to the XRD results and the $\mathrm{H} / \mathrm{C}$ and $\mathrm{O} / \mathrm{C}$ ratios. The hydrothermal treatment from both wastes in the presence of phosphoric acid also promoted the precipitation of macronutrients of the vinasse as phosphate phases such as $\mathrm{MgKPO}_{4} \cdot 6 \mathrm{H}_{2} \mathrm{O}$, $\mathrm{MgHPO}_{4} \cdot 1.2 \mathrm{H}_{2} \mathrm{O}, \quad \mathrm{Mg}_{3}\left(\mathrm{PO}_{4}\right)_{2} \cdot 22 \mathrm{H}_{2} \mathrm{O}, \quad \mathrm{Ca}_{3}\left(\mathrm{PO}_{4}\right)_{2}$ and $\mathrm{Ca}_{3}\left(\mathrm{P}_{3} \mathrm{O}_{9}\right)_{2} \cdot 10 \mathrm{H}_{2} \mathrm{O}$. Due to the presence of these compounds the ash contents of hydrochars were very high (above $10 \%$ ). Thus, the above mentioned characteristics identified in the hydrochars containing elements such as $\mathrm{N}$, $\mathrm{P}, \mathrm{Ca}, \mathrm{Mg}, \mathrm{K}$ and $\mathrm{C}$ and organic functional groups, suggest that these carbonaceous materials prepared from sugarcane bagasse and vinasse have a great potential for use as a fertilizer to improve soil quality.

Acknowledgments The authors are grateful to Central Analítica UFC/CT-INFRA/MCTI-SISNANO/Pro-Equipamentos CAPES for providing the scanning electron microscopes and the Laboratório de Sucroquímica e Química Analítica - UNESP/IBILCE for providing the infrared spectrometer. O. P. F and M. C. B. also acknowledge support from CNPq (Grants 478743/2013-0 and 445487/2014-3) and FUNCAP (PRONEX PR2-0101-00006.01.00/15). We also appreciate the financial support and scholarship from FAPESP (Grants 2013/21776-7 and 2014/22400-3).

\section{References}

1. Karp, S., Woiciechowski, A., Soccol, V., Soccol, C.: Pretreatment strategies for delignification of sugarcane bagasse: a review. Braz. Arch. Biol. Techn. 56(4), 679-689 (2013)

2. Moraes, B.S., Zaiat, M., Bonomi, A.: Anaerobic digestion of vinasse from sugarcane ethanol production in Brazil: challenges and perspectives. Renew. Sust. Energ. Rev. 44, 888-903 (2015)

3. Rolim, M.M., Lyra, M.R.C.C., Duarte, A.S., Medeiros, P.R.F., Silva, E.F.F., Pedrosa, E.M.R.: Influência de uma lagoa de distribuição de vinhaça na qualidade da água. Revista Ambiente Água 8, 155-171 (2013)

4. Loh, Y.R., Sujan, D., Rahman, M.E., Das, C.A.: Sugarcane bagasse-The future composite material: a literature review. Resour. Conserv. Recy. 75, 14-22 (2013)

5. Libra, J.A., Ro, K.S., Kammann, C., Funke, A., Berge, N.D., Neubauer, Y., Titirici, M.M., Fuhner, C., Bens, O., Kern, J.: Hydrothermal carbonization of biomass residuals: a comparative review of the chemistry, processes and applications of wet and dry pyrolysis. Biofuels 2(1), 89-124 (2011)

6. Titirici, M., White, R., Falco, C., Sevilla, M.: Black perspectives for a green future: hydrothermal carbons for environment protection and energy storage. Energ. Environ. Sci. 5(5), 6796-6822 (2012)

7. Roman, S., Nabais, J., Laginhas, C., Ledesma, B., Gonzalez, J.: Hydrothermal carbonization as an effective way of densifying the energy content of biomass. Fuel Process. Technol. 103, 78-83 (2012)

8. Xue, Y., Gao, B., Yao, Y., Inyang, M., Zhang, M., Zimmerman, A., Ro, K.: Hydrogen peroxide modification enhances the ability of biochar (hydrochar) produced from hydrothermal carbonization of peanut hull to remove aqueous heavy metals: Batch and column tests. Chem. Eng. J. 200, 673-680 (2012)

9. Bargmann, I., Rillig, M., Kruse, A., Greef, J., Kucke, M.: Effects of hydrochar application on the dynamics of soluble nitrogen in soils and on plant availability. J. Plant Nutr. Soil Sc. 177(1), 48-58 (2014)

10. Cernansky, R.: State-of-the-art soil. Nature 517(7534), 258-260 (2015)

11. Berge, N., Ro, K., Mao, J., Flora, J., Chappell, M., Bae, S.: Hydrothermal carbonization of municipal waste streams. Environ. Sci. Technol. 45(13), 5696-5703 (2011)

12. Lu, X., Pellechia, P., Flora, J., Berge, N.: Influence of reaction time and temperature on product formation and characteristics associated with the hydrothermal carbonization of cellulose. Bioresour. Technol. 138, 180-190 (2013)

13. Sabio, E., Álvarez-Murillo, A., Roman, S., Ledesma, B.: Conversion of tomato-peel waste into solid fuel by hydrothermal carbonization: influence of the processing variables. Waste Manage. 47, 122-132 (2016)

14. Chen, W., Ye, S., Sheen, H.: Hydrothermal carbonization of sugarcane bagasse via wet torrefaction in association with microwave heating. Bioresour. Technol. 118, 195-203 (2012)

15. Hoekman, S., Broch, A., Robbins, C., Zielinska, B., Felix, L.: Hydrothermal carbonization (HTC) of selected woody and herbaceous biomass feedstocks. Biomass Conv. Bioref. 3, 113-126 (2013)

16. ASTM: Standard Test Method for Chemical Analysis of Wood Charcoal. Method D1762-84. ASTM International, Pennsylvania (2013)

17. EPA: Soil and waste pH. Method 9045D. Environmental Protection Agency, Washington, DC (2004)

18. Reza, M., Wirth, B., Luder, U., Werner, M.: Behavior of selected hydrolyzed and dehydrated products during hydrothermal carbonization of biomass. Bioresour. Technol. 169, 352-361 (2014)

19. Basso, D., Patuzzi, F., Castello, D., Baratieri, M., Rada, E., Firi, L., Weiss-Hortala, E.: Agro-industrial waste to solid biofuel through hydrothermal carbonization. Waste Manage. 47, 114-121 (2016)

20. Kang, S., Li, X., Fan, J., Chang, J.: Characterization of hydrochars produced by hydrothermal carbonization of lignin, cellulose, D-xylose, and wood meal. Ind. Eng. Chem. Res. 51(26), 9023-9031 (2012)

21. EPA: Acid Digestion of Sediments, Sludges and Soils. Method 3050B. Environmental Protection Agency, Washington, DC (1996)

22. APHA: Standard Methods for the Examination of Water and Wastewater, 21st edn. American Public Health Association, American Water Works Association, Water Environment Federation, Washington, DC (2005)

23. He, C., Giannis, A., Wang, J.: Conversion of sewage sludge to clean solid fuel using hydrothermal carbonization: hydrochar fuel characteristics and combustion behavior. Appl. Energ. 111, 257-266 (2013) 
24. Wiedner, K., Naisse, C., Rumpel, C., Pozzi, A., Wieczorek, P., Glaser, B.: Chemical modification of biomass residues during hydrothermal carbonization-What makes the difference, temperature or feedstock? Org. Geochem. 54, 91-100 (2013)

25. Xu, Q., Qian, Q.F., Quek, A., Ai, N., Zeng, G.N., Wang, J.W.: Hydrothermal carbonization of macroalgae and the effects of experimental parameters on the properties of hydrochars. Acs Sustain. Chem. Eng. 1(9), 1092-1101 (2013)

26. Sato, S., Comerford, N.: Influence of soil $\mathrm{pH}$ on inorganic phosphorus sorption and desorption in a humid Brazilian ultisol. Rev. Bras. Cienc. Solo 29(5), 685-694 (2005)

27. Danso-Boateng, E., Shama, G., Wheatley, A., Martin, S., Holdich, R.: Hydrothermal carbonisation of sewage sludge: effect of process conditions on product characteristics and methane production. Bioresour. Technol. 177, 318-327 (2015)

28. Funke, A., Ziegler, F.: Hydrothermal carbonization of biomass: a summary and discussion of chemical mechanisms for process engineering. Biofuel. Bioprod. Bior. 4(2), 160-177 (2010)

29. Liu, F., Guo, M.: Comparison of the characteristics of hydrothermal carbons derived from holocellulose and crude biomass. J. Mater. Sci. 50(4), 1624-1631 (2015)

30. Oliveira, I., Blohse, D., Ramke, H.: Hydrothermal carbonization of agricultural residues. Bioresour. Technol. 142, 138-146 (2013)

31. Inoue, S., Sawayama, S., Dote, Y., Ogi, T.: Behaviour of nitrogen during liquefaction of dewatered sewage sludge. Biomass Bioenerg. 12(6), 473-475 (1997)

32. Ramsurn, H., Kumar, S., Gupta, R.: Enhancement of biochar gasification in alkali hydrothermal medium by passivation of inorganic components using $\mathrm{Ca}(\mathrm{OH})(2)$. Energ. Fuel. 25(5), 2389-2398 (2011)

33. van Krevelen, D.W.: Coal: Typology-Physics-Chemistry-Constitution. Elsevier, Amsterdam (1993)
34. Bekele, A., Roy, J.L., Young, M.A.: Use of biochar and oxidized lignite for reconstructing a functioning topsoil: plant growth response and soil nutrient concentrations. Soil Sci. 178(7), 344-358 (2013)

35. Xu, K., Li, J., Zheng, M., Zhang, C., Xie, T., Wang, C.: The precipitation of magnesium potassium phosphate hexahydrate for $\mathrm{P}$ and $\mathrm{K}$ recovery from synthetic urine. Water Res. 80, 71-79 (2015)

36. Parshetti, G., Hoekman, S., Balasubramanian, R.: Chemical, structural and combustion characteristics of carbonaceous products obtained by hydrothermal carbonization of palm empty fruit bunches. Bioresour. Technol. 135, 683-689 (2013)

37. Yuan, J., Xu, R., Zhang, H.: The forms of alkalis in the biochar produced from crop residues at different temperatures. Bioresour. Technol. 102(3), 3488-3497 (2011)

38. Handke, M., Mozgawa, W.: Vibrational spectroscopy of the amorphous silicates. Vib. Spectrosc. 5(1), 75-84 (1993)

39. Kabyemela, B., Adschiri, T., Malaluan, R., Arai, K.: Glucose and fructose decomposition in subcritical and supercritical water: detailed reaction pathway, mechanisms, and kinetics. Ind. Eng. Chem. Res. 38(8), 2888-2895 (1999)

40. Karampasa, I., Kontoyannisa, C.: Characterization of calcium phosphates mixtures. Vib. Spectrosc. 64, 126-133 (2013)

41. Nakamoto, K.: Infrared and Raman Spectra of Inorganic and Coordination Compounds. John Wiley \& Sons, Hoboken (2009)

42. Makreski, P., Jovanovski, G., Dimitrovska, S.: Minerals from Macedonia XIV. Identification of some sulfate minerals by vibrational (infrared and Raman) spectroscopy. Vib. Spectrosc. 39, 229-239 (2005)

43. Gao, Y., Wang, X., Yang, H., Chen, H.: Characterization of products from hydrothermal treatments of cellulose. Energy 42(1), 457-465 (2013) 